\title{
THE LINGUISTIC FEATURES OF INDONESIAN CHILDREN POETRY
}

Tri Mulyono, Agus Nuryatin, Rustono, and Suminto A Sayuti

University Pancasakti Tegal, State University of Semarang, State University of

Semarang, Yogyakarta State University

upstrimulyono@gmail.com

DOI: https://doi.org/10.24071/ijhs.2018.010208

received 11 December 2017; revised 30 January 2018; accepted 19 February 2018

\begin{abstract}
This study was inspired by the fact that the study in the field of children literature is rarely found in today's era, especially the study of poetry. Even though there are a lot of children poetries written by child poets nowadays, but still the research in children poetry is still low. Therefore, the researchers conducted this study which is expected to enrich study in the field of children literature. Specifically, this study limited its objective into describing the language features of Indonesian children poetry. To pursue such objective, this study employed 50 titles of Indonesian children poems written by child poets. The data of those poetries were collected by reading and writing (recording). Once the data were collected, they were analyzed in descriptive qualitative. The results show that the linguistic features of Indonesian children poetry written by child poets is foregrounded by having these features: word shortening, meaning deviation, the use of foreign language words and Javanese language.
\end{abstract}

Keywords: literary work, linguistic features, Indonesian children poetry

\section{Introduction}

If carefully observed, so far literature studies are mostly done in the field of adult literature such as studies conducted on Sapardi's poetries, short stories of Ahmad Tohari, and drama scripts of Arifin C Noor. This proves that children literature studies are rarely done. It is quite disappointing that Indonesian children literatures have been written a lot nowadays, not to mention children poetry.

A lot of children literatures can be easily found in media close to our daily life. For example, Suara Merdeka (Central Java) daily newspaper which releases children poetries every Sunday. The same thing is done by Kompas (Jakarta) newpaper. On the one hand, Bobo children's magazine also releases three poems of Indonesian children at once in its publication. Meanwhile, the poetries found among those media are such as Abdurahman Faiz (2005) with his poems under the title of Aku Ini Puisi Cinta (I am the love poetry), Neva Zahrani (2016), a child poet who published her poetry while she was still in the fifth grade of elementary school entitled Andai Aku Jadi Presiden (If I were a president). Rampan (2014) also does not want to miss chance of publishing his own literary 
work. He selected short stories and poems from various sources, then published them with the title Balon Keinginan (The Balloon of Whises).

Although the children poetries have been written a lot, but research on it has not been done quite often yet lately. It is proven by the absence of the study focusing on children literatures in International Conference on Language, Literature, and Teaching (FBS Unnes, 2017) held on 10 October 2017 at Hotel MG Setos Semarang. It was found that among 80 paper, there was even no paper discussing children poetry.

Given that the poetry of Indonesian children has not been much discussed, therefore this article is written to discuss children's poetry. The discussion is conducted with the aim to describe the linguistic features of Indonesian children poetry.

Sudjiman (1986) mentions that poetry is a literary variety whose language is bound by rhythm, rhyme, and dimension as well as number of lines and stanzas. In this case, literary variety means literary works. In line with this, Wellek and Warren (2014) states that literary variety covers poetry, fiction prose, and drama.

In his book entitled Anatomi Sastra (The Anatomy of Literature), Semi (1984) quotes Mulyana, Wordworth, and Arnold on the meaning of poetry. According to Mulyana poetry is the synthesis of the various events of the language that has been filtered purely and the various processes of the soul who seek the essence of its experience, and arranged with a correspondence system in one form. First, poetry is the synthesis of various language events. It means that poetry is a braid of life events or experiences such as the braid of grief and sorrow, sadness and joy.

Second, the language event has been filtered purely in the process of choosing words or diction. Thus, a poet or writer carefully choses words in expressing his idea. The chosen words are only those which are worth to represent poets' ideas. For example, Chairil Anwar uses different title in publishing his poetry. The one was published with the title of "Aku" (I am ), while another was entitled "Semangat" (spirit).

Third, the language event is composed by correspondence system in one form. In this case, correspondence system is realized in form attachment. Although poetry consists of a number of stanzas, and each stanza consists of a number of lines, but the whole is a unity. That is what so called as a valuable poem.

William Worsworth says that poetry is the best word in the best order. Only the best words the poet chooses to express his ideas. The idea is expressed in its best form. Inside that good form contains a good verse, enjambment, and homologues.

Alternatively, Mathew Arnold argues that poetry is a criticism of life. That is the same as what was said by one of the former President of the United States, John F. Kennedy that when politics is dirty then the poem will clean it.

On the other hand, children poetry is a poetry that is deliberately written for the target audience of children. Meanwhile, the categorization of children put forward by Erikson, Huck, and Piaget. As quoted by Saadie and Tarigan (1993, p. 54), Ericson argues that based on the human nature development, children are divided into four, namely:

1. trust (obtained at the age of 1 year); 
2. a sense of autonomy (realized at the age of 3 years);

3. a sense of initiative (evolving between 3-6 years);

4. a sense of duty (growing between 6-12 years).

Based on the above human nature category, children are referred to those who are in the range of 1 to 12 years old. In other words, children are those who are in elementary school age (SD). Huck, et al (1987: 64-72) suggests that based on the suitable reading materials for children, the meaning of children is:

1. those who are before school or who are in growth (age 1 and 2 years);

2. those in preschool and right-kindergarten (ages 3-5 years);

3. those in the early school (age 6 and 7 years);

4. those who are in the middle elementary period (ages 8 and 9 years), and

5. those who are in the final elementary period (10-12 years of age).

Under the Huck category, children are also those who are aged 1 to 12 years. As quoted Brady (Sexby, 1991), according to Peaget's level of intellectual development, children are divided into four groups. They are as follows:

1. motor sensory stage. That is those who are at the age of $0-2$ years;

2. preoperational stage. That is those who are at the age of 2-7 years;

3. concrete operational stage. That is those who are aged 7-11 years;

4. formal operational stage. That is those who are at the age of 11-12 years.

Based on the Peaget category, children are those who are between 1 and 12 years of age. Thus, children poetry is a poetry written to read by those aged 1 to 12. Poetry is part of a literary work because literary works cover poetry, fiction prose, and drama. Thus, every trait which is in the literary work is a characteristic of poetry as well. Not excluded the characteristics of Indonesian children poetry. Sarumpaet (1976, p.24) for example, puts forward three characteristics of literary works which are the characteristics of children's poetry as well, namely the existence of a number of abstinence, directness, and applicable.

Not every theme can be written for children poetry. Themes like marriage, divorce, polygamy are not worth writing for children to read. Thus, the themes that are generally written for children's poetry are themes of parents and teachers, animals and the natural and religious environment.

The language of Indonesian children's poetry is straightforward. Its meaning is not convoluted rather to be easily understood. This is due to the level of reasoning of children who have not been complicated and still simple. Applicable means can be practiced or proven in everyday life. Thus, the idea of Indonesian children poetry can be sourced from sensory experience; For example, based on something that has been seen, something has ever been heard, or something the poet once ever felt.

When thoroughly observed, the characteristics of the literary works have not been based on the linguistic aspect, whereas literature and poetry in particular is an imaginative work with language as a means of disclosure. Considering this, this study examined the characteristics of poetry based on aspects of language that have not been presented by Sarumpaet.

Nurgiyantoro (2005, pp.321-353) mentions that the elements of children poetry builders are sounds, words, means of rhetoric, and themes. Further, a 
poetry composed by language means contains the element of sound. It is because language is a system of symbols of sound. For example, the poetry entitled "aku" is the composition of the sound element of a-k-u. The meaning of sound here is primarily the various forms of sound financing such as alliteration, assonance, anaphora, epistrophe, and rhyme. What is meant by word in the previous explanation is word selection. To produce the desired meaning and rhyme, the poet needs to choose words. Rahardi (2010, p.31) mentions that the choice of the word actually questiones "the ability of a word, phrase, or group of words to give the right idea to the image of the reader or hearer." To find the desired word, it is not uncommon for a poet to deviate and destroy (distortion) the words. Nurgiyantoro (2005, p.335) states that meaning deviation includes the omission or word shortening, the use of foreign or Javanese words, and meaning divergence. These three aspects will be analyzed as the marker of the linguistic features of Indonesian children poetry.

\section{Method}

This research was conducted with the data source of 50 Indonesian children poetries written by child poets. Those were chosen based on the consideration that all the poetries are loaded with aspects to be analyzed according to the purpose of his research. For more, the manuscripts of the study were taken from various sources, namely Bobo children magazine and the collection book of poetry entitled Balon Keinginan (The Balloon of Wishes) by Rampan's Wish (2014). The selection of the compilation book was caused by the difficulty in getting the original source of the poetry.

The data from the above source were collected by reading the poetries repeatedly and then being noted or recorded with the data units of words, phrases, lines, and stanzas. Specifically, the recording process was done by using data card. Meanwhile, the research instrument was the researcher himself. Once the data has been collected, they were analyzed descriptively qualitative. Further, the collected data were coded, classified based on the subject of the study, and interpreted based on relevant references. At last, the conclusions were done inductively.

The validity of this study was tested using semantic and intra-rater validity. The semantic validity was done by interpreting the parts of the research subject based on the structure and discourse shown, while intra-rater validity was done by reading poetry carefully and repeatedly until the necessary data were found. Meanwhile, the credibility of interpretation was done by consulting the data with three experts as mentors, namely Agus Nuryatin (Unnes), Suminto A Sayuti (UNY), and Rustono (Unnes).

\section{Findings and Discussion}

It was mentioned earlier that the linguistic features of Indonesian children poetry cover word shortening, meaning deviation, and the use of a foreign or Javanese language.

\section{Word Shortening}

The word shortening was found in 28 titles of poetries. Those are "Gunung Kok Bangun Tidur" (What Makes a Mountain Wakes Up from its sleep?), "Ayah" (Father), "Narkoba" (Drugs), "Mengenang Pak Harto" (Remembering Mr. Harto), 
"Ayah Bundaku” (My Father and Mother), "Ayah Bunda Tersayang” (My Lovely Father and Mother), "Ayahku Tidak Merokok" (My Father Does not Smoke), "Matahari” (Sun), "Almari” (Cupboard), "Bonekaku” (My Dolls), "Terima Kasih Sepatuku" (Thanks, My Shoes), "Bulan Sakit" (The Sick Moon), "Waktu” (Time), "Bidadariku" (My Fairy), "Hadiahku" (My Gifts), "Naik Kelas" (Promoted to the Next Grade), "Penghapus" (Eraser), "BBM" (Fuel), "Papaku” (My Dad), "Hatiku yang Hilang" (My Missing Heart), "Raden Ajeng Kartini", "R.A Kartini", "Guruku" (My Teacher), "Pengamen Cilik di Lampu Merah" (Young Artists at Traffic Light), "Bila Burung Pipit di Bilik Rumahku" (When a Sparrow is on My Room), "Anak Ayam" (Chicks), dan "Guru” (Teacher).

The shortened words found were such as the shortening of the words "tetapi" (but) into "tapi", "engkau" (you) into "kau", "tidak" (not) into "tak", "aku" (I) into "ku", "menjadi" (become) into "jadi", "berbau" (smell) into "bau", "akan" (will) into "kan", "telah" (has/ have been) into "tlah", and "mencari" (look for) into "cari". The word tapi is the shortened form of the original word tetapi. It was found in the poetry entitled "Gunung Kok Bangun Tidur" in stanza II.

Tapi tiba-tiba kau bangun dari tidur (but you suddenly wake up from your sleep)

Menggeliat dengan getaran di perut Bumi

(squirming along with the vibration in the bowels of the Earth)

Menyemburkan asap, panas ke atas Bumi

(spouting hot smoke onto the Earth)

Lalu meletus dahsyat tinggi menjulur

(and then strongly erupt onto the sky)

The word "tak" is the shortened form of the original word "tidak". It was found in several poetries. One of which is in the poetry of "Naik Kelas". In this poetry, the word "tak" was found in stanza II.

Akhirnya buku biru itu kuterima

(I finally received that book)

Buku rapor namanya

(the name is rapor or the book containing the final score in a semester)

Kubuka....

(when I opened it)

Tak ada angka enam!

(there was either no six)

Tak ada angka lima!

(or five!)

The word "ku" is the shortened form of the original word "aku". The use of " $k u$ " word shortening was found in a poetry entitled "Hatiku yang Hilang". In that poetry, the word "ku" was found in line seven. The following is the excerpt.

Hatiku...

(My heart)

Hatiku tlah hilang

(It is missing)

Tak tahu hilang ke mana 
(I don't know where it is)

Mungkin hilang

(it may be lost)

Dimakan kegelapan malam

(in the dark of the night)

Yang sunyi senyap

(that is silent)

Kini ku bersedih

(I am now sad)

Kini kumenyesal

(I regret)

Tlah menelantarkan hatiku

(abandoning my heart)

Hatiku yang penuh

(my heart which is full)

Misteri cerita

(the mystery of stories)

Meanwhile, the word "jadi" is the shortened form of the original word "menjadi", the word "bau" is the shortened form of the word "berbau", the word "kan" is the shortened form of the original word "akan", the word "tlah" is the shortened form of the original word "telah". Also the word "cari" is the shortened form of the original word "mencari",

Other than word shortening, Indonesian children poetries also contain meaning deviation. It is showed in the following analyses.

\section{Meaning Deviation}

Meaning deviation is resulted by the utilization of language style such as the use of metaphor, metonymy, simile, and personification. According to the data analysis, the researcher found that the meaning deviation was caused by personification. Personification is the man-like language style applied on noun outside human. It was found in several poetries, namely "Gunung Kok Bangun Tidur", "Narkoba", "Ayah Bundaku", "Matahari", "Bulan Sakit", and "Bidadariku”.

The example of this personification is in the poetry entitled "Gunung Kok Bangun Tidur". In this poetry, a mountain is admitted as a human being. It can sleep and be invited to talk like human. The following excerpt shows it.

Kata ilmuwan... kau tidur Panjang

(Scientists say that you are sleeping in the long period)

Kata peneliti, kau sudah mati

(They also say that you are dead already)

Dan tak mungkin hidup kembali

(and impossible to be alive again)

Kata pakar, kau cuma tiang pancang

(experts say that you are just a pile)

Yang terus diam sepanjang zaman

(which always remain silent all the time)

Tapi tiba-tiba kau bangun dari tidur

(but you suddenly wake up from your sleep) 
Menggeliat dengan getaran di perut Bumi

(squirming along with the vibration in the bowels of the Earth)

Menyemburkan asap, panas ke atas Bumi

(spouting hot smoke onto the Earth)

Lalu meletus dahsyat tinggi menjulur

(and then strongly erupt onto the sky)

Another personification was found in the poetry entitled "Narkoba". It is also admitted as a human being who have polluted, poisoned, and tormented people by the poet. The following excerpt shows it.

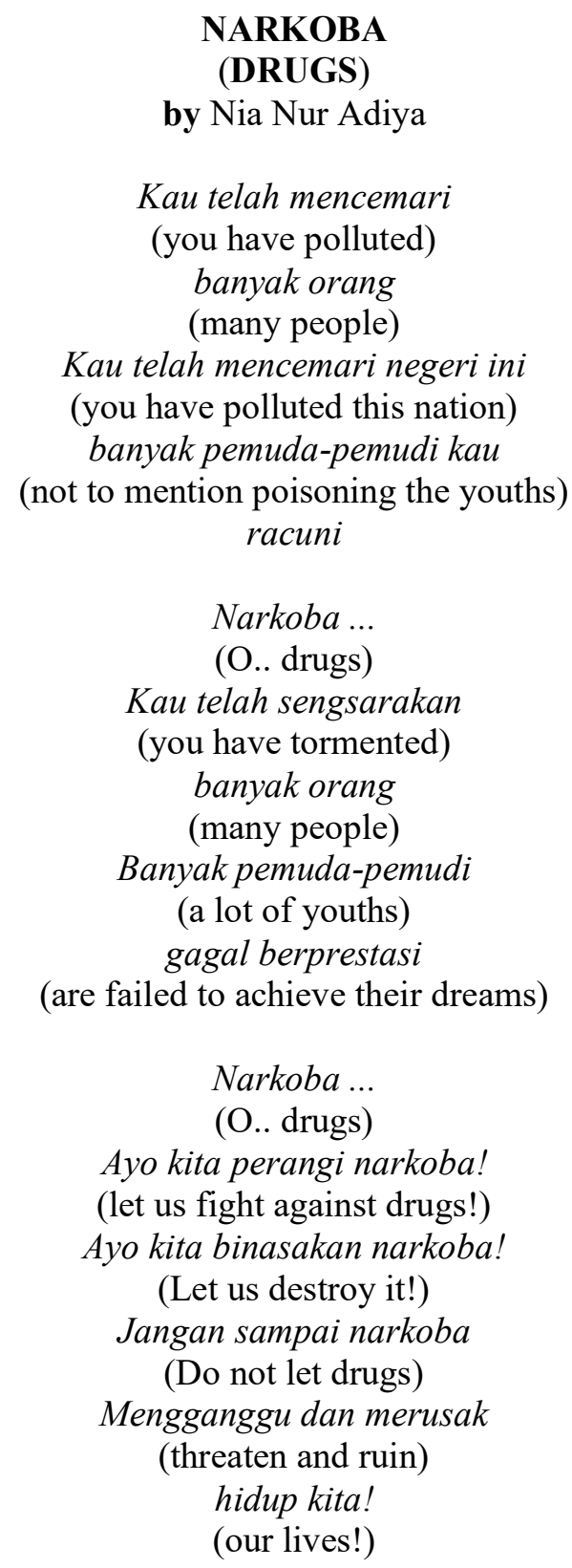

For more, personification was also found in a poetry entitled "Matahari". In this poetry, the sun is admitted as a human being. It was greeted by the use of 
word "kau" (you), the same as what is used for human being. The following excerpt shows it.

\section{Matahari}

(O.. sun)

Kau menyinari dunia

(you shine the world)

Kami hangat karena kau

(we feel warm because of you)

Kau membantu semua orang

(you help all people)

Semua nyaman karena engkau

(all feels comfortable because of you)

In the poetry entitled "Bulan Sakit", the researcher also found a personification. As what happens to human being, the moon is also said to be able to get illness. The following excerpt shows it.

Aku duduk di tangga masjid

(I was sitting at the stairs of a mosque)

Sambil melihat ke atas

(while starring at the sky)

Aku menemukan Bulan separuhnya hilang

(I found the moon was lost its half part)

Juga bersinar merah

(and also shined the red light)

Kukira bulan itu mau muncul

(I though it was about to appear)

Tapi kulihat atlas

(but when I looked into atlas)

Kalau bulan separuhnya berwarna merah

(that the moon apparently had its half part in the red color)

Katanya dia sedang sakit

(someone said that she was ill)

Aku sedih....

(I was sad)

Aku tak mau bulan sakit

(I did not want to see the moon got ill)

Aku mau bulan menerangi malam-malamku

(I want it to illuminate my nights)

Beside word shortening and meaning deviation, Indonesian children poetry also contains the use of Javanese or foreign language. The following description shows it.

\section{The Use of Foreign Language Words}

The use of foreign language words was found in the poetries of "Mengenang Pak Harto", "Ayah Bundaku”, "Ayahku Tidak Merokok", "Luar Angkasa” (Space), "Bonekaku”, "Guruku”, "Waktu yang Terbuang” (The Wasted Time), and "Olahraga" (Sports). The example of the use of foreign 
language words is taken from the poetry of "Mengenang Pak Harto". It was found that this poetry uses the word "surga" (heaven) which is a word coming from Arabic language.

Several poetries also use foreign language words. For example, in the poetry entitled "Ayah Bundaku" the researcher found the word "surge", in "Luar Angkasa" poetry the researcher found the word "astronot" that is a word coming from English, in "Guruku" poetry the researcher found a word "heroic" that is a word coming from English, in "Waktu yang Terbuang" poetry the researcher found words "iman" (belief) and "ibadah" (prayer) which are words coming from Arabic language, and in "Olahraga" poetry the researcher found words "jiwa" (soul)), "raga" (body), and "men sana in corpore sano" which are words coming from Sanskrit language.

A Javanese language word were also found in the poetry entitled "Bonekaku" that is by the use of the word "imut" (little).

\section{Conclusion}

Based on the above elaboration, it can be concluded that in order to create the beauty of poetry, a poet does word selection. It is realized in the form of word shortening, meaning deviation, and the use of foreign language as well as Indonesia local language. Overall, those are the linguistic features of Indonesian children poetry.

\section{Acknowledgements}

The completion of this study cannot be separated from the supervision of three experts, namely Mr. Agus Nuryatin (Unnes), Mr. Suminto A Sayuti (UNY), and Mr. Rustono (Unnes). Therefore, the researcher would like to give sincere thanks to all of those three experts.

\section{References}

Hahardi, K. (2010). Bahasa Indonesia untuk perguruan tinggi. Jakarta: Penerbit Erlangga.

Huck, C.S., et al. (1987). Children literature in the elementary school. New York: Holt Rinehard and Winston in.

Mulyono, T. (2017). Struktur dan nilai estetika pada puisi anak-anak Indonesia. Semarang: Draf Disertasi.

Nurgiyantoro, B. (2005). Sastra anak: Pengantar dunia anak. Yogyakarta: Gadjah Mada University Press

Rampan, K.L. (2014). Balon keinginan. Bandung: Yrama Widya.

Sarumpaet, R.K. (1976). Bacaan anak-anak suatu penyelidikan pendahuluan ke dalam hakikat, sifat, dan corak bacaan anak-anak serta minat anak pada bacaannya. Jakarta: Pustaka Jaya.

Saxby, M. \& Winch, G (Eds). (1991). Give them wings, the experience of children's literature. Melbourne: The Macmillan Company.

Semi, M.A. (1984). Anatomi sastra. Padang: Angkasa Raya.

Tarigan, H.G. (1995). Dasar-dasar psikosastra. Bandung: Angkasa. 